\title{
Interannual variability of ecosystem carbon exchange: From observation to prediction
}

\author{
Shuli Niu1,2 (1) | Zheng Fu'1,2 | Yiqi Luo ${ }^{3}$ | Paul C. Stoy ${ }^{4}$ | Trevor F. Keenan ${ }^{5}$ \\ Benjamin Poulter ${ }^{6}$ | Leiming Zhang ${ }^{1,2}$ | Shilong Piao7 | Xuhui Zhou ${ }^{8}$ | \\ Han Zheng ${ }^{1,9}$ | Jiayin Han ${ }^{1,2}$ | Qiufeng Wang1,2 | Guirui Yu1,2
}

\author{
${ }^{1}$ Key Laboratory of Ecosystem Network Observation and Modeling, Institute of Geographic Sciences and Natural Resources Research, Chinese Academy of Sciences, \\ Beijing, China \\ ${ }^{2}$ University of Chinese Academy of Sciences, No. 19A Yuquan Road, Beijing, 100049, China \\ ${ }^{3}$ Department of Microbiology and Plant Biology, University of Oklahoma, Norman, Oklahoma \\ ${ }^{4}$ Department of Land Resources and Environmental Sciences, Montana State University, Bozeman, Montana \\ ${ }^{5}$ Climate and Ecosystem Sciences Division, Lawrence Berkeley National Laboratory, Berkeley, California \\ ${ }^{6}$ Goddard Space Flight Center, NASA, Greenbelt, Maryland \\ ${ }^{7}$ College of Urban and Environmental Sciences, Peking University, Beijing, 100871, China \\ ${ }^{8}$ Tiantong National Forest Ecosystem Observation and Research Station, School of Ecological and Environmental Sciences, East China Normal University, Shanghai, \\ China \\ ${ }^{9}$ State Key Laboratory of Loess and Quaternary Geology, Institute of Earth Environment, Chinese Academy of Sciences, Xi'an, 710061, China
}

\section{Correspondence Shuli Niu, Synthesis Research Center of Chinese Ecosystem Research Network, Key Laboratory of Ecosystem Network Observation and Modeling, Institute of Geographic Sciences and Natural Resources Research, Chinese Academy of Sciences, Beijing 100101, China. \\ Email: sniu@igsnrr.ac.cn}

\section{Funding information}

National Natural Science Foundation of China, Grant/Award Numbers: 31625006 and 31420103917; Ministry of Science and Technology of China, Grant/Award Number: 2016YFC0501803; Thousand Youth Talents Plan; U.S. National Science Foundation Division of Environmental Biology, Grant/Award Number: 1552976

Editor: Martin Sykes

\begin{abstract}
Aim: Terrestrial ecosystems have sequestered, on average, the equivalent of $30 \%$ of anthropogenic carbon $(C)$ emissions during the past decades, but annual sequestration varies from year to year. For effective $C$ management, it is imperative to develop a predictive understanding of the interannual variability (IAV) of terrestrial net ecosystem C exchange (NEE).

Location: Global terrestrial ecosystems.

Methods: We conducted a comprehensive review to examine the IAV of NEE at global, regional and ecosystem scales. Then we outlined a conceptual framework for understanding how anomalies in climate factors impact ecological processes of $\mathrm{C}$ cycling and thus influence the IAV of NEE through biogeochemical regulation.

Results: The phenomenon of IAV in land NEE has been ubiquitously observed at global, regional and ecosystem scales. Global IAV is often attributable to either tropical or semi-arid regions, or to some combination thereof, which is still under debate. Previous studies focus on identifying climate factors as driving forces of IAV, whereas biological mechanisms underlying the IAV of ecosystem NEE are less clear. We found that climate anomalies affect the IAV of NEE primarily through their differential impacts on ecosystem $\mathrm{C}$ uptake and respiration. Moreover, recent studies suggest that the carbon uptake period makes less contribution than the carbon uptake amplitude to IAV in NEE. Although land models incorporate most processes underlying IAV, their efficacy to predict the IAV in NEE remains low.
\end{abstract}

Main conclusions: To improve our ability to predict future IAV of the terrestrial $\mathrm{C}$ cycle, we have to understand biological mechanisms through which anomalies in climate factors cause the IAV of NEE. Future research needs to pay more attention not only to the differential effects of climate 
anomalies on photosynthesis and respiration but also to the relative importance of the $\mathrm{C}$ uptake period and amplitude in causing the IAV of NEE. Ultimately, we need multiple independent approaches, such as benchmark analysis, data assimilation and time-series statistics, to integrate data, modelling frameworks and theory to improve our ability to predict future IAV in the terrestrial C cycle.

\section{KEYWORDS}

climate change, interannual variability, net ecosystem exchange, photosynthesis, respiration

\section{1 | INTRODUCTION}

Terrestrial ecosystems have sequestered an average of nearly $30 \%$ of anthropogenic $\mathrm{CO}_{2}$ emissions since the 1960s (Ballantyne, Alden, Miller, Tans, \& White, 2012; Le Quéré et al., 2014). However, the magnitude of this terrestrial carbon (C) sequestration varies from year to year (Le Quéré et al., 2013), changing from a c. $0.5 \mathrm{Gt} \mathrm{C}$ /year C source in 1987 to a $4.0 \mathrm{Gt} \mathrm{C/year} \mathrm{C} \mathrm{sink} \mathrm{in}$ 2011. The large interannual variability (IAV) of land C uptake, rather than oceanic $C$ uptake, primarily contributes to the yearly variation in atmospheric $\mathrm{CO}_{2}$ concentration (Figure 1; Bousquet et al., 2000; Houghton, 2000; Knorr et al., 2007). Thus, understanding the causes of the interannual variability (IAV) in land $C$ sequestration is essential for future projections of the coupled $C$ cycle and climate system. At ecosystem scales, many studies have also found that the IAV of net ecosystem $\mathrm{CO}_{2}$ exchange (NEE) with the atmosphere is a ubiquitous phenomenon across almost all sites of eddy-flux measurements (Baldocchi, Chu, \& Reichstein, 2017; Baldocchi, Falge, Gu, et al., 2001; Baldocchi, Ryu, \& Keenan, 2016; Yuan et al., 2009). However, the mechanisms underlying the IAV in NEE across scales from the ecosystem to the globe have not been fully understood to an extent that can help improve our predictive capability of the $\mathrm{C}$ cycle. If the IAV of NEE is caused purely by climatic variability, we can extrapolate measurements from one year to another year as long as we have realistic climatic data and scenarios. If climate variability induces indirect effects on ecosystem processes via biogeochemical regulation, we need long-term observations to develop sound understanding of relationships between NEE and climatic variables before we can reasonably predict $C$ fluxes. In these circumstances, ecological models that do not include appropriate mechanisms often successfully simulate NEE in one year but fail in others (Griffis \& Rouse, 2001; Keenan, Baker, et al., 2012).

This paper comprehensively assesses the current status of our understanding of the IAV of the land $\mathrm{C}$ sink. We first review literature on the phenomena of the IAV of the land C sink at global, regional and ecosystem scales, and then identify regional contributions to the global IAV of NEE and the driving climate factors and biological mechanisms underlying the IAV of NEE at the ecosystem scale. We then evaluate model efficacy in predicting IAV and explore causes for the mismatches between models and data. Finally, we offer recommendations for future studies to measure and model IAV better in order to improve our predictive understanding of the global $C$ cycle. This review suggests that the IAV in NEE results from anomalies in climatic variables, such as temperature, precipitation and radiation, which differentially influence photosynthetic $C$ uptake and respiratory $C$ release processes through biological regulation.
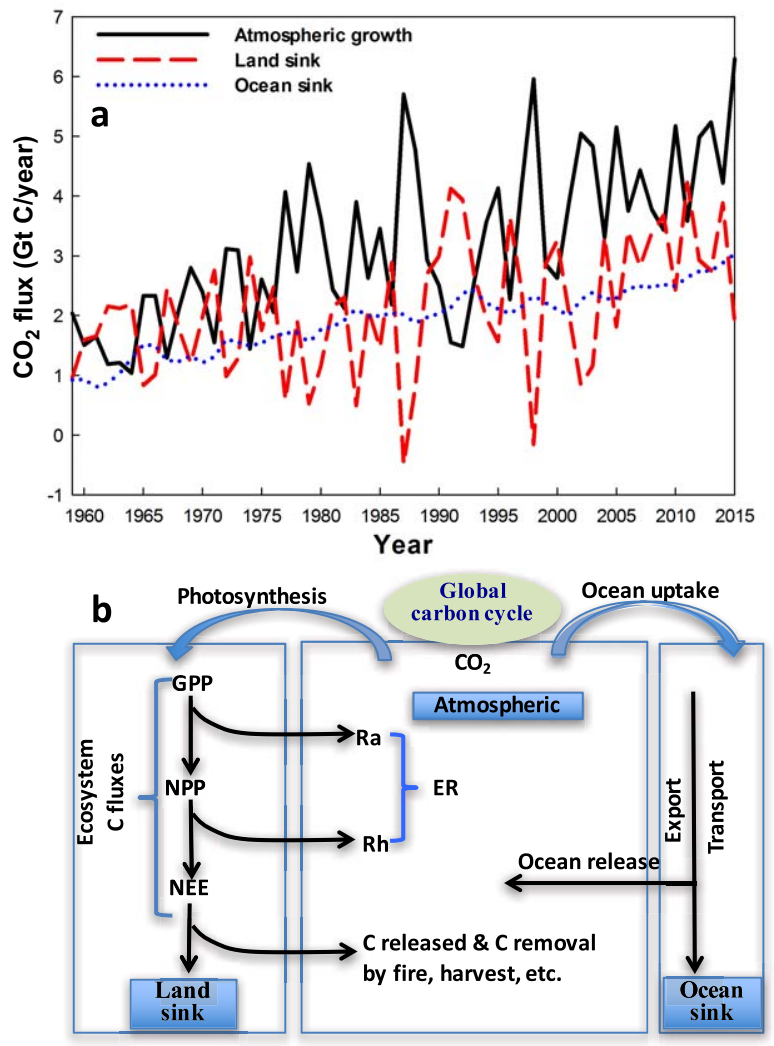

FIGURE 1 (a) The interannual variability of atmospheric $\mathrm{CO}_{2}$ growth rate, land and ocean carbon sinks from 1958 to 2015. (b) Conceptual diagram linking the terms and processes used in this review.

Atmospheric $\mathrm{CO}_{2}$ is taken up by the land and the ocean. In terrestrial ecosystems, plants take up $\mathrm{CO}_{2}$ to form gross primary productivity (GPP). Some of the photosynthetic carbohydrate is released into the atmosphere via autotrophic respiration (Ra). The remaining carbohydrate forms net primary productivity (NPP). Soil organic matter is decomposed by microbes via heterotrophic respiration (Rh) to release $\mathrm{CO}_{2}$ into the atmosphere. The balance of carbon uptake and release at the ecosystem level forms net ecosystem exchange (NEE). At the regional or global scale, the land carbon (c) sink is formed by excluding non-biotic $\mathrm{C}$ release or removal caused by fire, harvest or other disturbances 


\section{I OBSERVED PHENOMENA OF INTERANNUAL VARIATION IN LAND CARBON SINK AT GLOBAL AND ECOSYSTEM SCALES}

The phenomenon of the IAV of the $\mathrm{C}$ cycle was first reported from long-term measurements of the atmospheric $\mathrm{CO}_{2}$ mixing ratio at the South Pole (Keeling, Adams, et al., 1976) and Mauna Loa observatories (Keeling, Bacastow, et al., 1976). At those observatories, the long-term change in the atmospheric $\mathrm{CO}_{2}$ growth rate was found to be highly variable; it could double or halve from one year to the next. This fluctuation was first considered to be associated with the Southern Oscillation and primarily oceanic events (Bacastow, 1976). The phenomenon of IAV of atmospheric $\mathrm{CO}_{2}$ concentration was then detected again from the measurement of 2,419 samples of air collected in the North Pacific Ocean during 1959-1981 (Keeling, Whorf, Wong, \& Bellagay, 1985). The data record of atmospheric $\mathrm{CO}_{2}$ observations is now more than five decades long, and the annual growth rate continues to exhibit high variability, with rates spanning an order of magnitude from as low as 0.29 ppmv in 1964 to as high as $3.15 \mathrm{ppmv}$ in 2015 (esrl.noaa.gov).

The anomaly in the annual growth rate of atmospheric $\mathrm{CO}_{2}$ concentration is now primarily attributed to the IAV in the land $\mathrm{C}$ sink (Figure 1; Houghton, 2000; Le Quéré et al., 2013). Houghton (2000) reviewed the four components that determine the atmospheric $\mathrm{CO}_{2}$ growth rate: $\mathrm{C}$ emissions from fossil fuel burning, net $\mathrm{C}$ emissions from land use changes, ocean uptake, and the residual land sink. His review concluded that the most important contributor to the IAV of atmospheric $\mathrm{CO}_{2}$ growth rate is the changes in land sink as induced by anomalies in climate variables. The IAV in ocean $\mathrm{CO}_{2}$ uptake is thought to be too small to explain the anomaly in atmospheric $\mathrm{CO}_{2}$ growth rate (Le Quéré, Orr, Monfray, Aumont, \& Madec, 2000). In comparison, the land $\mathrm{C}$ sink can strongly regulate the atmospheric $\mathrm{CO}_{2}$ growth rate to the extent of no increase between 2002 and 2012 despite increasing anthropogenic emissions (Keenan et al., 2016).

Both atmospheric inversions and ground-based observations show that the land $C$ sink varies greatly from year to year. Estimates of NEE at the global scale from atmospheric inversion approaches showed that the detrended global NEE ranged from an anomaly of $1.78 \mathrm{Pg} \mathrm{C} /$ year in 1983 to $-1.66 \mathrm{Pg} \mathrm{C}$ /year in 1992 in comparison with the mean value of NEE of $-1.52 \mathrm{Pg} \mathrm{C} /$ year over the 35 years (Figure 2a). At regional scales, some tropical regions had the largest IAV, with SD in annual gross primary production (GPP) of the order of 200-250 g C/ $\mathrm{m}^{2}$ (Xiao et al., 2016). Relative to the long-term mean, GPP over Europe decreased by $30 \%$ in 2002 because of drought when comparing the period between 1998 and 2002, resulting in a strong anomalous net source of NEE (0.5 Pg C/year) to the atmosphere, which is a net $C$ sink during normal years (Ciais et al., 2005).

The IAVs of the land $C$ sink at global and regional scales are in agreement with observations at ecosystem scales. For example, the observed NEE by the eddy covariance towers changed from 74 to $930 \mathrm{~g} \mathrm{C} / \mathrm{m}^{2} /$ year at the site US-Blo (Blodgett Forest in the Sierra
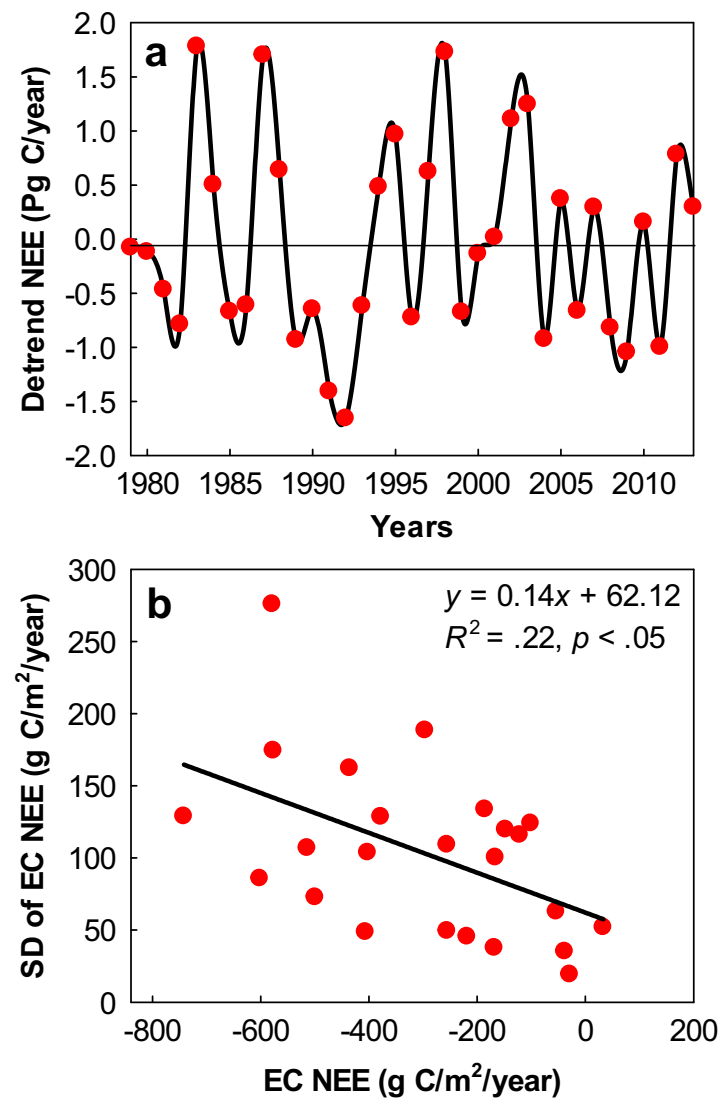

FIGURE 2 Interannual variability of terrestrial ecosystem carbon fluxes at (a) global and (b) ecosystem scales. (a) The detrended yearly anomaly of atmospheric inversed net ecosystem exchange (NEE) at the global scale from 1978 to 2013. (b) The SD of eddy covariance (EC) measured NEE versus its average annual values at 24 sites with measurements $>8$ years. See the Supporting Information for detailed methods

Mountains of California) and from -158 to $240 \mathrm{~g} \mathrm{C} / \mathrm{m}^{2} /$ year at the site Be-Bra (De Inslag Forest in Brasschaat, Belgium) during the period from 1997 to 2007 (Fu, Stoy, et al., 2017). Across the 24 sites that have $>8$ years of continuous measurement, the SD of NEE on average accounts for $50 \%$ of annual NEE (Figure $2 \mathrm{~b}$ ). Besides eddy covariancemeasured NEE at the ecosystem scale, other observations, such as tree-ring chronologies, showed large IAV in wood production in response to climate variability (Carrer \& Urbinati, 2006). Results from long-term ecological research (LTER) programmes have also demonstrated strong IAV in aboveground net primary productivity (NPP), which is associated with precipitation changes, at 11 LTER sites across North America (Knapp \& Smith, 2001).

Overall, scientists have used different approaches to quantify the IAV of land NEE at different spatial scales. The top-down atmospheric method using $\mathrm{CO}_{2}$ inversions is effective to illustrate the global scale IAV, whereas the flux-tower observations have the advantage of providing process understanding of the IAV of NEE at the ecosystem scale. Nonetheless, inferences from both atmospheric inversions and observations at the ecosystem scale indicate that the IAV of ecosystem $C$ exchange is a ubiquitous phenomenon. 


\section{3 | REGIONAL CONTRIBUTIONS TO THE INTERANNUAL VARIATION OF GLOBAL LAND CARBON SINK}

The IAV of the global land C sink is attributable to different regions; for example, tropical areas are reported to play an important role in influencing the IAV of terrestrial NEE (W. Wang et al., 2013; X. Wang et al., 2014). Specifically, the IAV of the tropical land $C$ sink is significantly correlated with tropical land-surface air temperature during 19592011 , with an interannual temperature sensitivity of $3.5 \pm 0.6 \mathrm{Pg} \mathrm{C} /$ year/K. The relationship between interannual changes in NEE and temperature in tropical areas appears to be stronger than corresponding relationships with precipitation and radiation (W. Wang et al., 2013). Moreover, X. Wang et al. (2014) found that the sensitivity of land C sink variability to tropical temperature IAV varies with time and has increased by a factor of $1.9 \pm 0.3$ over the past five decades. Across coupled climate-carbon cycle models, the sensitivity of tropical land C sink to climate anomaly over the 21st century is constrained to be $53 \pm 17 \mathrm{Pg} \mathrm{C} / \mathrm{K}$ (Cox et al., 2013).

Recent studies have also shown that semi-arid areas lead to a larger contribution to the IAV of the land $\mathrm{C}$ sink than other regions (Ahlström et al., 2015; Poulter et al., 2014). Specifically, semi-arid systems contributed c. $39 \%$ of the IAV in global net biome production, compared with tropical ecosystems (19\%), extratropical forests (30\%) and grasslands and croplands (17\%) (Ahlström et al., 2015). Semi-arid regions contributed $57 \%$ of the global IAV of global GPP, which was controlled by the IAV of precipitation in these regions (Y. Zhang et al., 2016). In semi-arid regions, vegetation is sparse and productivity is typically low compared with tropical and boreal systems given strong water deficits in semi-arid regions (Avitabile et al., 2016; Beer et al., 2010). However, ecosystem C fluxes can respond quickly to precipitation events (e.g. Huxman et al., 2004), leading to a unique land C sink signature. It is important also to note that transient $\mathrm{CO}_{2}$ release attributable to the 'Birch' effect in response to precipitation pulses is a notable property of arid and semi-arid ecosystems (Birch, 1958; Unger, Máguas, Pereira, David, \& Werner, 2010). Whereas the Birch effect operates at shorter temporal scales (hours to weeks), associated respiratory pulses can add up to impact the IAV of NEE (Jarvis et al., 2007). The sensitivity of semi-arid systems to an increasing frequency of precipitation extremes is noticeable in global land $C$ uptake dynamics (Ahlström et al., 2015; Frank et al., 2015), further demonstrating the central role of semi-arid ecosystems in the IAV of terrestrial $\mathrm{CO}_{2}$ fluxes.

The debate regarding the role of temperature in tropical regions and precipitation in semi-arid regions on the IAV of global land $C$ uptake is proposed to be resolved by a recent study, which simultaneously evaluated the IAV of land C uptake to the fluctuations in both temperature and water availability at local to global scales (Jung et al., 2017). Jung et al. (2017) revealed that water availability and temperature are the dominant drivers of IAV of NEE at local areas, whereas temperature is the main driver for the global IAV of NEE because of the compensation amongst the responses of different regions to water availability (Figure 3). In other words, the controlling factors and mechanisms underlying the IAV of NEE varied at different spatial scales

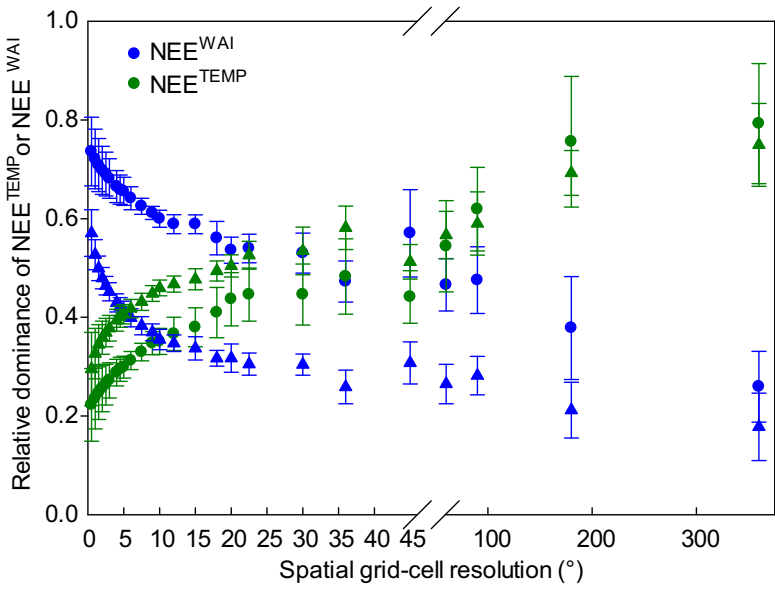

FIGURE 3 The relative importance of temperature versus water availability in causing the interannual variability of land net ecosystem exchange (NEE) at different spatial scales. The relative dominance of temperature on NEE (NEE ${ }^{\text {TEMP }}$ ) increases, whereas the relative dominance of water availability on NEE (NEE ${ }^{\text {WAl }}$ ) decreases, with increasing spatial scales (adopted from Jung et al., 2017)

(Table 1), and the importance of IAV at the ecosystem or local scales would be cancelled out when aggregating to a regional or global scale. Therefore, to gain a better understanding of the IAV of land C uptake, it is necessary to understand ecosystem-level NEE variability and the mechanisms that control it.

\section{4 | THE IMPORTANCE OF CLIMATE AND OTHER FORCING FACTORS TO THE INTERANNUAL VARIATION OF ECOSYSTEM NET ECOSYSTEM $\mathrm{CO}_{2}$ EXCHANGE}

Studies on the causes of the IAV of ecosystem NEE usually examine the relationship between the yearly anomalies of NEE and the anomalies of climate factors. Variations in temperature, precipitation and solar radiation have been reported as the most important climate factors controlling IAV in NEE in different ecosystems. Below, we discuss how those climate and other forcing factors impact IAV of NEE, with a focus on the mechanisms and process understanding.

\section{1 | Drought and precipitation regimes}

The timing and magnitude of precipitation regimes influences GPP and ecosystem respiration (ER), thus causing variability of NEE (see the concepts in Figure 1b). Water availability is the overall dominant driver of the IAV in NEE at local scales (Jung et al., 2017). Drought causes IAV of NEE in most ecosystems, even those not commonly associated with drought, such as tropical forests (Keppel-Aleks et al., 2014; Ma et al., 2012; Xiao et al., 2014; L. Zhang et al., 2014). Amazon basinwide net ecosystem productivity (NEP, the inverse of NEE) was reduced in drought years (Gatti et al., 2014). In wet tropical forests, drought considerably reduces respiration, but tends to impact GPP less, as a consequence of increased light availability (Bonal et al., 2008; 
TABLE 1 Scales of phenomena, driving factors, biological mechanisms and future research recommendations for understanding the interannual variability of net ecosystem carbon dioxide exchange

\begin{tabular}{|c|c|c|c|}
\hline & Global & Regional & Ecosystem \\
\hline Phenomena & $\begin{array}{l}\text { Variation in yearly growth rate of } \\
\text { atmospheric } \mathrm{CO}_{2} \text { concentration }\end{array}$ & $\begin{array}{l}\text { Yearly anomalies of regional NEE } \\
\text { under heat waves, large-scale } \\
\text { drought and fires }\end{array}$ & $\begin{array}{l}\text { Yearly variation in NEE observed by } \\
\text { eddy-flux towers, NPP from long- } \\
\text { term ecological research sites, tree } \\
\text { rings }\end{array}$ \\
\hline Driving factors & Primarily anomalies of temperature & $\begin{array}{l}\text { Anomalies of both temperature and } \\
\text { precipitation, with varying roles in } \\
\text { different regions }\end{array}$ & $\begin{array}{l}\text { Temperature, precipitation, radiation } \\
\text { and disturbances play different } \\
\text { roles in different ecosystems }\end{array}$ \\
\hline Model predictive skill & $\begin{array}{l}\text { No mechanistic models yet tested } \\
\text { except some statistical models }\end{array}$ & $\begin{array}{l}\text { Land models used to examine IAV in } \\
\text { different regions }\end{array}$ & $\begin{array}{l}\text { Models perform poorly, mainly be- } \\
\text { cause of a lack of model calibra- } \\
\text { tion of phenological and } \\
\text { physiological responses, and lag } \\
\text { mechanisms }\end{array}$ \\
\hline
\end{tabular}

Abbreviations: IAV = interannual variability; NEE = net ecosystem carbon dioxide exchange; NPP = net primary productivity.

Saleska et al., 2003). In temperate ecosystems, however, eddy covariance observations indicate that drought-induced reductions in GPP often exceed those of ER, leading to a reduction in ecosystem carbon uptake (Schwalm et al., 2010; Shi et al., 2014). Drought-induced IAV of GPP (Cai et al., 2014; Zscheischler et al., 2014) is primarily attributable to the associated decrease in stomatal conductance (Novick et al., 2016; Zeng, Mariotti, \& Wetzel, 2005) and increases in vegetation mortality, dry woody material and wildfire occurrence (X. Zhang et al., 2013). The magnitude of changes in those biogeochemical processes are related to drought intensity and duration, the plant functional type (Welp, Randerson, \& Liu, 2007), soil characteristics (Pinter, Balogh, \& Nagy, 2010) and topography (Kljun et al., 2006).

Besides the amount of precipitation, other attributes of precipitation regimes (e.g., the magnitude, frequency, interval and seasonal distribution of precipitation events) are also responsible for the IAV of NEE (Guo et al., 2012). For some ecosystems, significant differences in the timing and magnitude of precipitation events are more important than annual precipitation itself for determining the IAV of NEE. For example, $\mathrm{C}$ sequestration often occurs after heavy precipitation in arid and semi-arid regions, including temperate regions with high evaporative demand (Novick et al., 2004), whereas smaller precipitation events often only stimulate respiratory responses of microorganisms (Huxman et al., 2004; Reynolds, Kemp, Ogle, \& Fernández, 2004).

Precipitation can affect $\mathrm{C}$ cycling through its effects on soil water content (SWC) (Knapp et al., 2008), temperature (Guo et al., 2015) and incident radiation (Nijp et al., 2015) and also through its regulation of soil nutrient availability and species composition (Sala \& Lauenroth, 1982). The effects of precipitation regimes on the IAV of the $C$ cycle are often ecosystem specific. Studies have found that precipitation regimes with larger but fewer precipitation events may have opposite effects on productivity in semi-arid ecosystems (Heisler-White, Knapp, \& Kelly, 2008; Thomey et al., 2011) versus meadows or relatively humid ecosystems (Fay, Carlisle, Knapp, Blair, \& Collins, 2003; Harper, Blair, Fay, Knapp, \& Carlisle, 2005; Heisler-White, Blair, Kelly, Harmoney, \& Knapp, 2009; Knapp et al., 2008). Therefore, biological mechanisms modify $\mathrm{C}$ cycling in response to precipitation regimes (Figure 4). Lengthening of growing seasons can partly offset the effects of drought (Wolf et al., 2016) on annual NEE, further emphasizing the importance of multiple factors in controlling the IAV of NEE.

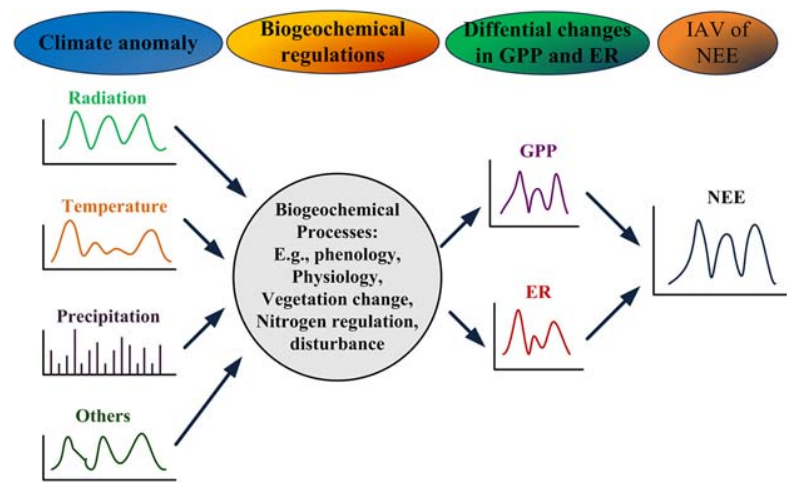

FIGURE 4 Schematic diagram for the conceptual relationships between climate anomalies, biogeochemical regulation and the interannual variability of carbon fluxes. Interannual variability (IAV) in net ecosystem exchange (NEE) is ultimately caused by anomaly in climate variables, which influence a variety of biogeochemical processes, resulting in differential changes in photosynthesis (gross primary productivity, GPP) and respiration (ecosystem respiration, ER) 


\subsection{Temperature}

Temperature affects all aspects of ecosystem C processes, including photosynthesis and respiration. Increasing temperature can directly stimulate enzyme activity and accelerate both photosynthesis and respiration rates, or reduce them through enzyme denaturation if temperature becomes too high. If the photosynthesis and respiration of plants and ecosystems are significantly different in response to temperature changes, the IAV of NEE will have a statistical correlation with annual average temperature (Rocha \& Goulden, 2008; Wen, Wang, Wang, Yu, $\&$ Sun, 2010). Field experiments suggest that climate warming also tends to extend growing seasons, enhance nutrient availability, shift species composition and alter ecosystem water dynamics (Luo, 2007), which further affects the IAV of NEE.

Even if the IAV of NEE may not have a significant relationship with the anomalies of mean annual temperature for a given ecosystem, it is often correlated with the anomalies of growing season temperature. For example, spring temperature helps to determine forest leaf onset and affects the length of the growing season, thus leading to the IAV of NEE (Richardson et al., 2013; Wu et al., 2012). Many studies have found that annual ecosystem $C$ fluxes are closely correlated with spring temperature across years (Keenan et al., 2014; Krishnan et al., 2008). In addition, autumn temperature changes are significantly correlated with changes in GPP and NEE (J. Zhang et al., 2011). Autumn and winter temperature anomalies may affect respiration more than photosynthesis given the negligible or minor contribution of photosynthesis to NEE during those seasons (Piao et al., 2008; Yuan et al., 2009) and can result in lagged effects to subsequent growing seasons (Barford et al., 2001). Thus, besides the direct effects of temperature on the physiological activities of photosynthesis and respiration, temperature change may also cause the IAV of $\mathrm{C}$ fluxes by changing plant phenology and growing season, as illustrated in the conceptual Figure 4.

\section{3 | Radiation}

Radiation has a more important role than climate factors at local scales, although it is a smaller driver of IAV of fluxes at the global scale, which experiences little year-to-year variability in solar radiation (Jung et al., 2017). Light-sensitive ecosystems respond to interannual changes in light availability, and in fact, minor drought can increase the photosynthesis of tropical forests if it results in more light (Oliphant et al., 2011). Radiation causes the IAV of terrestrial GPP not only via its magnitude but also via light quality (Ichii, Hashimoto, Nemani, \& White, 2005; Nemani et al., 2003). Diffuse radiation has a large influence on the IAV of NEE (Cox et al., 2013; Reichenau \& Esser, 2003). For instance, Gu et al. (2003) described the effects of the Pinatubo volcano eruption in 1991, which produced a large number of volcanic aerosols, resulting in the worldwide increase of diffuse radiation in the following 2 years on temperate forest NEE. The increase in diffuse radiation enhanced noontime photosynthesis at Harvard Forest in cloudless conditions by $23 \%$ in 1992 and 8\% in 1993, respectively. Another study by Mercado et al. (2009) suggested that the increasing fraction of diffuse radition resulted in a $23.7 \%$ increase in global terrestrial C sink between 1960 and 1999.

In general, diffuse radiation influences the IAV of NEE at least in four ways. First, the increasing clouds and aerosols change the composition of the radiation spectrum (Gatebe, Kuznetsov, \& Melnikova, 2014; Navrátil, Špunda, Marková, \& Janouš, 2007) and increase the proportion of blue light (van Gorsel et al., 2013). Second, increasing clouds and aerosols decrease direct radiation, reducing the frequency of light saturation of canopy photosynthesis and making the canopy more responsive to changes in radiation (Farquhar \& Roderick, 2003; Knohl \& Baldocchi, 2008). Third, the increasing clouds and aerosols, to a certain extent, simultaneously reduce temperature, which decreases ecosystem respiration (M. Zhang et al., 2010, 2011). Fourth, diffuse radiation penetrates the plant canopy more effectively, which can increase total canopy photosynthesis (Cheng et al., 2015; Roderick, Farquhar, Berry, \& Noble, 2001). Combined, these factors influence both photosynthesis and radiation and demonstrate the need to include diffuse radiation measurements at tower measurements worldwide to understand the relationship between solar radiation and the IAV of ecosystem NEE.

\section{4 | Other driving factors}

Fires and other disturbances, such as pests and disease, can induce $\mathrm{C}$ release from ecosystems to the atmosphere. Approximately $70 \%$ of global fire $\mathrm{CO}_{2}$ emissions are from savanna and grassland systems, where regrowth occurs rapidly after a fire and absorbs a significant fraction of $\mathrm{CO}_{2}$, which is often of similar magnitude to the original emissions. The $\mathrm{C}$ loss triggered by the fire event in one area can be compensated by $C$ gain during recovery in other areas. Thus, on average, fire plays a minor role in the IAV of land C uptake at global scales (Van der Werf et al., 2010), but is often an important contributing factor to regional $C$ fluxes, especially in relationship to drought (Poulter et al., 2014). A synthesis of multiple data sources of atmospheric $\mathrm{CO}_{2}$ growth rate, land use change, fire emission and land carbon fluxes showed a significant correlation between atmospheric $\mathrm{CO}_{2}$ growth rate and fire emission, but the magnitude in variation attributable to fire emission was too small to explain the IAV of $\mathrm{CO}_{2}$ growth rate (S. L. Piao, unpublished result). Global emission of $\mathrm{C}$ from human disturbance (i.e. deforestation, shifting cultivation, wood harvest and regrowth) or pests or diseases also has a small contribution to the IAV of global land C uptake (Houghton, 2010).

\section{5 | BIOLOGICAL MECHANISMS UNDERLYING INTERANNUAL VARIATION IN ECOSYSTEM NET ECOSYSTEM $\mathrm{CO}_{2}$ EXCHANGE}

The apparent relationships between climate anomalies and the IAV of ecosystem NEE suggest underlying ecological mechanisms, which are essential for explaining the impacts of climate anomalies on ecosystem C cycling. Here, we synthesize studies on biological mechanisms into three categories: statistical inference, differential changes in GPP and 
ER, and relative contributions of ecosystem $C$ uptake phenology and physiology to the IAV of ecosystem NEE.

\section{1 | Statistical inference of biotic controls on interannual variation of ecosystem net ecosystem $\mathrm{CO}_{2}$ exchange}

Variability in climate drivers may directly affect fluxes, but may also indirectly affect fluxes by altering the response of biota to climate (Figure 4). To isolate direct effects of climatic anomalies on ecosystem metabolic processes (e.g., photosynthesis and respiration) from their indirect effects, Hui, Luo, and Katul (2003) proposed a homogeneityof-slopes model to identify the functional change contributing to IAV in NEE. The model uses multiple regression analysis to partition the observed variation in NEE to four components, namely, the functional change, the direct effect of interannual climatic variability, the direct effect of seasonal climatic variation, and random error. The results showed that functional change provided slightly larger explanation than interannual climatic variability for the observed variation in NEE and ecosystem respiration (RE) at the Duke Forest AmeriFlux site from 1997 to 2001 (Hui et al., 2003). Using the same statistical method, Shao et al. (2015) evaluated the relative contributions of climate effect and biotic effect to the IAV in C fluxes for the 65 sites in the Northern Hemisphere. They found that overall, the relative contribution of biotic effect and climate effect to the IAV in NEE was $57 \pm 14$ and $43 \pm 14 \%$, respectively. Similar results were documented by Richardson, Hollinger, Aber, Ollinger, and Braswell (2007), who suggested that $40 \%$ of the variance in modelled ecosystem NEE can be attributed to variation in environmental drivers, and $55 \%$ to variation in the biotic response to this forcing at the annual time step. Polley, Frank, Sanabria, and Phillips (2008) also used the regression analysis proposed by Hui et al. (2003) to distinguish direct effects of IAV in climate on fluxes from biotic effect (functional change) and found that functional change accounted for more than twice the variance in fluxes of direct effects of climatic variability. These studies highlight how the IAV of NEE is strongly regulated by the response of ecological processes, such as plant photosynthesis and respiration, as well as phenology and physiology, to climate variability (Figure 4).

\section{2 | Differential changes in photosynthesis and respiration}

Observed NEE reflects a fine balance between canopy photosynthetic $C$ influx into and respiratory efflux out of an ecosystem (Figure 1b). Differential changes in the relative magnitude of these two opposite fluxes determine the IAV of NEE (Figure 4). Carbon fluxes attributable to photosynthesis and respiration are large relative to the difference between them (i.e. NEE), which means that small differences in the relative changes in photosynthesis or respiration can lead to large IAV of NEE. For the climate sensitivity of photosynthesis and respiration, some studies reported that ecosystem respiration is more variable than photosynthesis between years (Valentini et al., 2000), whereas other studies have indicated that IAV of NEE is most often associated with variations in GPP and NPP rather than C release (i.e., ecosystem respiration ( $\mathrm{Re}$ ) and heterotrophic respiration (Rh)) (Ahlström et al., 2015; Ciais et al., 2005; Novick et al., 2015; Stoy et al., 2008).

For the relative sensitivity of photosynthesis versus respiration in response to variability in controlling factors, it was found that GPP was more sensitive to drought stress than ER in most ecosystems, especially in semi-arid and mediterranean climates, which experience large variability in the amount of rainfall in the growing season (Allard, Ourcival, Rambal, Joffre, \& Rocheteau, 2008; Pereira et al., 2007). Nevertheless, temperature anomalies tend to change ER more than GPP (Yvon-Durocher, Jones, Trimmer, Woodward, \& Montoya, 2010). For example, based on a 9-year eddy covariance measurement record, years with autumnal warming reduced the annual $\mathrm{CO}_{2}$ sink because of the stimulation of ER in a black spruce forest (Ueyama, Iwata, \& Harazono, 2014). Moreover, nitrogen deposition tends to favour GPP more than ER at the ecosystem scale (Fernández-Martínez et al., 2014). Disturbance events (e.g., clear-cuts and fires), likewise change GPP as well as ER (Beringer, Hutley, Tapper, \& Cernusak, 2007). Despite decades of research on the GPP and ER, our ability to produce an estimate of global photosynthesis and respiration with a high accuracy confidence still remains elusive, needless to mention the mechanisms underlying their IAV. Future research on mechanisms underlying the IAV of ecosystem NEE has to provide fundamental explanations for the IAV of GPP and ER.

\section{3 | Relative contributions of carbon uptake phenology and physiology}

Climate change influences the terrestrial $\mathrm{C}$ cycle by modifying the $\mathrm{C}$ uptake rate and $C$ uptake period, which primarily correspond to plant physiology and phenology, respectively. It has been demonstrated that spatial and temporal variations in GPP are jointly controlled by changes in plant phenology and physiology (Xia et al., 2015). NEE is also strongly correlated with growing season length and regulated by plant phenology (Baldocchi, Falge, \& Wilson, 2001). Using NEE estimated through atmospheric inversion, the IAV of land C uptake was determined by the IAV of the $C$ uptake period and the $C$ uptake amplitude (the maximal $\mathrm{C}$ uptake rate), of which $\mathrm{C}$ uptake amplitude played much stronger role than C uptake period (Fu, Dong, et al., 2017). Likewise, analysis of regional GPP data products generated by a vegetation photosynthesis model also showed a dominant role of plant physiology in IAV of GPP in North America (Zhou et al., 2017).

As illustrated in the conceptual Figure 5, C uptake period or amplitude may change differently in various ecosystem types in response to climate change, resulting in different impacts on IAV of NEE (Fu, Stoy, et al., 2017). For example, in boreal or temperate ecosystems, warmer spring or autumn periods may lengthen the $C$ uptake period by advancing $C$ uptake activity in spring or by delaying $C$ uptake activity in autumn (Figure 5a,b). In subtropical forests or arid and semi-arid grasslands, summer drought may depress $\mathrm{C}$ uptake amplitude during the mid-growing season (Figure $5 c, d$ ).

The attribution of IAV of NEE to C uptake period and amplitude provides mechanistic explanations on how climate factors control the 
Advanced carbon uptake due
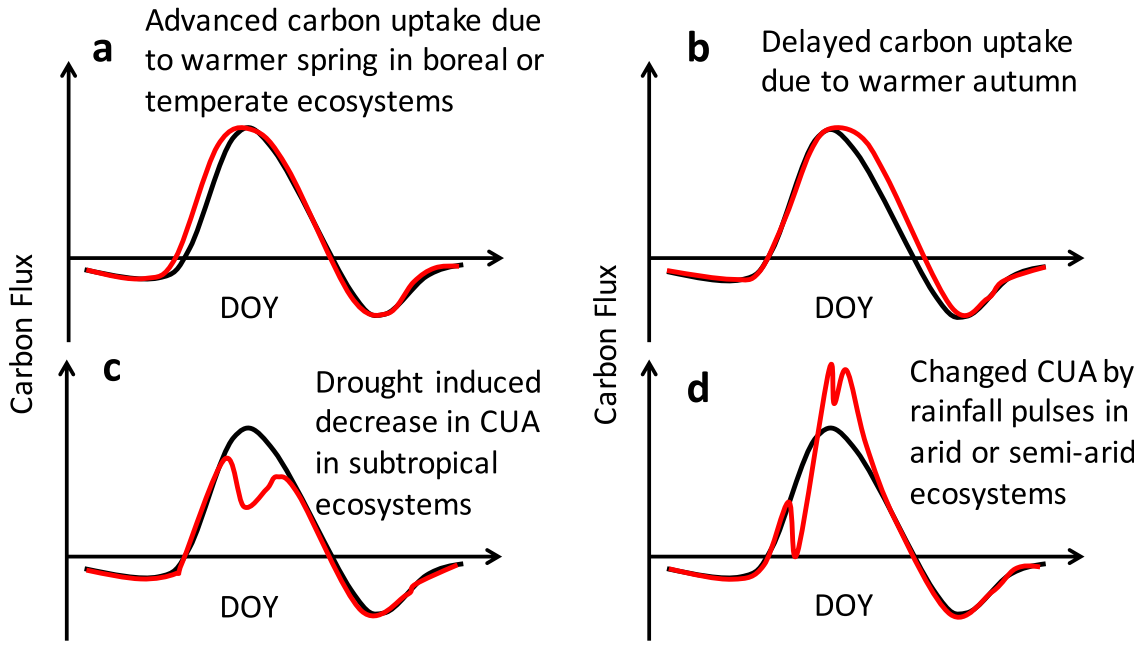

FIGURE 5 Conceptual figures for the attributions of carbon uptake period (carbon sink days) and carbon uptake amplitude (the maximal carbon uptake rate, CUA) to the interannual variability of ecosystem net carbon uptake. The black curve means the average year and the red curve indicates any specific year that changes in carbon uptake period and/or amplitude following Fu, Stoy, et al. (2017). DOY means day of the year

IAV of the terrestrial $\mathrm{C}$ cycle. Given that $\mathrm{C}$ uptake period and amplitude are two processes that occur in different seasons, they may have different controlling climatic factors (Fu, Stoy, et al., 2017). Climate factors may have compensatory effects on $\mathrm{C}$ uptake period and amplitude, leading to negligible impacts on annual NEP. For example, a longer growing season caused by spring warming may result in higher GPP or NEE, whereas warmer and drier summers may suppress summer production, potentially offsetting the increase in ecosystem $C$ uptake (Angert et al., 2005; Cleland, Chuine, Menzel, Mooney, \& Schwartz, 2007). The $C$ uptake period/amplitude framework provides a simple mechanism for understanding how ecosystem physiology and phenology interact with climate variables to influence the IAV of NEE and GPP.

\section{6 | CHALLENGES IN PREDICTING THE INTERANNUAL VARIATION OF THE LAND CARBON CYCLE}

The efficacy of land surface models for reproducing the observed IAV of the terrestrial carbon cycle depends on the scale of interest. At the global scale, the IAV of NEE is primarily determined by changes in tropical temperatures and precipitation (W. Wang et al., 2013), with large contributions in some years from semi-arid regions (Poulter et al., 2014) and high-latitude ecosystems (Ahlström et al., 2015). Such largescale global signals are driven by large-scale events, such as the El Nino Southern Oscillation, which itself remains difficult to predict (Kleeman \& Moore, 1997), as are the impacts of climate variability on IAV at the ecosystem scale.

Observations of IAV at the ecosystem scale provide an excellent opportunity to test land surface models, given that many anomalous climate events (such as summer heat waves and extreme droughts) often occur at specific sites. When tested against such site-scale observations, however, land surface models typically perform very poorly.
For example, Keenan, Baker, et al. (2012) tested 16 land surface models and three remote sensing products against observed IAV at 11 long-term observation sites and found that none of the models reproduced the observations. A lack of lagged responses to anomalous climatic events (Keenan, Baker, et al., 2012), a poor representation of phenological signals (Richardson et al., 2013) and model formulation (Dietze et al., 2011; Schwalm et al., 2010) have been highlighted as potential causes of model-data mismatch for IAV at the site scale. Integrating models with observations through data assimilation has proved useful in diagnosing the exogenous and endogenous causes of such model-data mismatch (Keenan, Davidson, et al., 2012). For example, Desai (2010) found that the ability of a land surface model to replicate IAV was significantly improved when observations were used to minimize parameter error through model-data fusion. Such approaches of better integrating models, data and theory (Luo, Keenan, \& Smith, 2015; Williams et al., 2009) should guide future efforts for improving our ability to model the IAV of NEE.

The mismatch between models and observations is often an issue of scale and initialization. Models tend to be parameterized using observations at the finest possible time-scale, either the half-hourly or hourly resolution that aligns with the native resolution of eddy covariance observations, or the sub-daily, daily or monthly time step of the model itself. This approach of conditioning models that are tuned to fine-scale data then aggregated to coarser scales in time often successfully matches NEE observations at diurnal to seasonal time-scales (Braswell, Sacks, Linder, \& Schimel, 2005; Stoy et al., 2013), but simulating annual NEE and its IAV remains stubbornly elusive (Figure 6). Despite extensive research using a number of advanced analytical techniques, including wavelet decomposition (Stoy et al., 2005), and techniques from model-data fusion, including scale-dependent parameter estimation (Mahecha et al., 2010), it is difficult to identify causal features in climate time series that correspond to ecosystem-scale fluxes at interannual time-scales (Stoy et al., 2009). A promising approach 


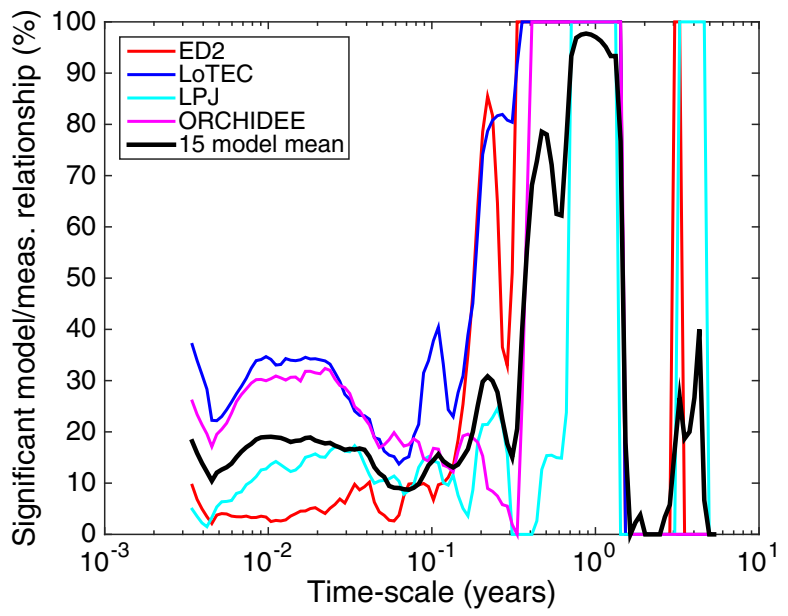

FIGURE 6 The percentage of time, at time-scales from days to multiple years, in which there is a significant relationship between eddy covariance measurements of net ecosystem exchange (NEE) at Harvard Forest and four different ecosystem models (including a multi-model mean) using the wavelet coherence approach of Grinsted, Moore, and Jevrejeva (2004) following Stoy et al. (2013)

that has been applied at the ecosystem level to understand connections between climate variables and ecosystem responses, including relationships among the coupled processes of GPP and ER, is spectral Granger causality (Detto et al., 2012). Spectral Grainger causality quantifies relationships amongst signals at different frequencies and thereby also IAV, but has not been used to help disentangle ecosystem responses to climatic variability at interannual time-scales to date. In brief, expanding our analytical toolbox may improve our ability to quantify nonlinear, lagged and multiscale relationships amongst climate and carbon cycling for the purpose of improving model representation of these dynamics.

\section{7 | CONCLUDING REMARKS AND FUTURE RESEARCH}

Interannual variability in terrestrial $C$ fluxes is a ubiquitous phenomenon at global, regional and ecosystem scales. The IAV in global land C fluxes is primarily responsible for the anomaly in atmospheric $\mathrm{CO}_{2}$ growth rate. However, linking the IAV of C fluxes across scales is still challenging. In particular, the regions that contribute most to the global IAV are still under debate, as are the contributions of these regions to global IAV in a changing climate. Tropical regions have been considered responsible for global IAV mainly because of their large climate variability related to El Niño/Southern Oscillation, and the arid and semi-arid regions also exhibit strong IAV signals.

Regardless of spatial scales, the IAVs in land C fluxes are ultimately attributable to climate variables, either directly or indirectly through biological responses to climate or via extreme events. It has been identified that anomalies in temperature, precipitation and radiation are key causes for IAV in ecosystem C fluxes. Radiation plays a key role locally but contributes less at the global scale. Precipitation anomalies are important to the IAV of NEE at local and regional scales but tend to be compensated globally, whereas the control of temperature over the IAV of NEE occurs at scales from the ecosystem to the globe. The anomalies in climate variables differentially influence photosynthetic $C$ uptake and respiratory $C$ release to generate IAV in NEE. As photosynthesis and respiration are two opposite fluxes determining NEE, slightly differential effects of anomalous temperature, precipitation and radiation on photosynthesis and respiration could generate strong IAV in NEE. Although a few studies have explored this issue, how anomalies in temperature, precipitation and radiation cause differential impacts on photosynthesis and respiration is largely unclear. Moreover, recent methodological advances improve our ability to understand relative contributions of the $\mathrm{C}$ uptake period and amplitude.

The present generation of ecosystem models has low predictive skills for IAV in NEE, although most of the key $\mathrm{C}$ processes have been integrated into models. Our understanding of the differential changes in photosynthesis and respiration in anomalous climate conditions has not yet been converted into improving model predictive skills. To develop our ability to predict IAV of NEE in the future, we have to understand the biological mechanisms underlying IAV of $C$ fluxes and evaluate their relative importance so that various mechanisms can be incorporated appropriately into models. Research efforts are also needed to benchmark land model performance against observations of IAV of ecosystem C fluxes (Luo et al., 2012). Data assimilation is an effective approach to minimizing model-observation mismatches and diagnosing model uncertainty, and new techniques from time-series analysis and statistics can further improve our ability to understand how climate and carbon interact. Better integration of models, data and theory should guide future efforts for improving our ability to predict the IAV of surface-atmosphere $C$ exchange at scales from the ecosystem to the globe.

\section{ACKNOWLEDGMENTS}

We thank Dr Martin Sykes and the two anonymous referees for their useful comments and suggestions. This work was financially supported by the National Natural Science Foundation of China (31625006, 31420103917), the Ministry of Science and Technology of China (2016YFC0501803) and the 'Thousand Youth Talents Plan'. P.C.S. acknowledges support from the U.S. National Science Foundation Division of Environmental Biology (1552976).

\section{ORCID}

Shuli Niu (D) http://orcid.org/0000-0002-2394-2864

\section{REFERENCES}

Ahlström, A., Raupach, M. R., Schurgers, G., Smith, B., Arneth, A., Jung, M., ... Zeng, N. (2015). The dominant role of semi-arid ecosystems in the trend and variability of the land $\mathrm{CO}_{2}$ sink. Science, 348, 895-899.

Allard, V., Ourcival, J., Rambal, S., Joffre, R., \& Rocheteau, A. (2008). Seasonal and annual variation of carbon exchange in an evergreen Mediterranean forest in southern France. Global Change Biology, 14, $714-725$ 
Angert, A., Biraud, S., Bonfils, C., Henning, C., Buermann, W., Pinzon, J., .. Fung, I. (2005). Drier summers cancel out the $\mathrm{CO}_{2}$ uptake enhancement induced by warmer springs. Proceedings of the National Academy of Sciences USA, 102, 10823-10827.

Avitabile, V., Herold, M., Heuvelink, G., Lewis, S. L., Phillips, O. L., Asner, G. P., ... Willcocks, S. (2016). An integrated pan-tropical biomass map using multiple reference datasets. Global Change Biology, 22, 1406-1420.

Bacastow, R. (1976). Modulation of atmospheric carbon dioxide by the Southern Oscillation. Nature, 261, 116-118.

Baldocchi, D., Chu, H., \& Reichstein, M. (2017). Inter-annual variability of net and gross ecosystem carbon fluxes: A review. Agricultural and Forest Meteorology. https://doi.org/10.1016/j.agrformet.2017.05. 015

Baldocchi, D., Falge, E., Gu, L., Olson, R., Hollinger, D., Running, S., ... Wofsy, S. (2001). FLUXNET: A new tool to study the temporal and spatial variability of ecosystem-scale carbon dioxide, water vapor, and energy flux densities. Bulletin of the American Meteorological Society, 82, 2415-2434.

Baldocchi, D., Falge, E., \& Wilson, K. (2001). A spectral analysis of biosphere-atmosphere trace gas flux densities and meteorological variables across hour to multi-year time scales. Agricultural and Forest Meteorology, 107, 1-27.

Baldocchi, D., Ryu, Y., \& Keenan, T. (2016). Terrestrial carbon cycle variability. F1000Research, 5, 2371. https://doi.org/10.12688/f1000research. 8962.1

Ballantyne, A., Alden, C., Miller, J., Tans, P., \& White, J. (2012). Increase in observed net carbon dioxide uptake by land and oceans during the past 50 years. Nature, 488, 70-72.

Barford, C. C., Wofsy, S. C., Goulden, M. L., Munger, J. W., Pyle, E. H., Urbanski, S. P., ... Moore, K. (2001). Factors controlling long-and short-term sequestration of atmospheric $\mathrm{CO}_{2}$ in a mid-latitude forest. Science, 294, 1688-1691.

Beer, C., Reichstein, M., Tomelleri, E., Ciais, P., Jung, M., Carvalhais, N., .. Papale, D. (2010). Terrestrial gross carbon dioxide uptake: Global distribution and covariation with climate. Science, 329, 834-838.

Beringer, J., Hutley, L. B., Tapper, N. J., \& Cernusak, L. A. (2007). Savanna fires and their impact on net ecosystem productivity in North Australia. Global Change Biology, 13, 990-1004.

Birch, H. (1958). The effect of soil drying on humus decomposition and nitrogen availability. Plant and Soil, 10, 9-31.

Bonal, D., Bosc, A., Ponton, S., Goret, J. Y., Burban, B., Gross, P., ... Granier, A. (2008). Impact of severe dry season on net ecosystem exchange in the Neotropical rainforest of French Guiana. Global Change Biology, 14, 1917-1933.

Bousquet, P., Peylin, P., Ciais, P., Le Quéré, C., Friedlingstein, P., \& Tans, P. P. (2000). Regional changes in carbon dioxide fluxes of land and oceans since 1980. Science, 290, 1342-1346.

Braswell, B. H., Sacks, W. J., Linder, E., \& Schimel, D. S. (2005). Estimating diurnal to annual ecosystem parameters by synthesis of a carbon flux model with eddy covariance net ecosystem exchange observations. Global Change Biology, 11, 335-355.

Cai, W., Borlace, S., Lengaigne, M., Van Rensch, P., Collins, M., Vecchi, G., ... Jin, F.-F. (2014). Increasing frequency of extreme El Niño events due to greenhouse warming. Nature Climate Change, 4, 111-116.

Carrer, M., \& Urbinati, C. (2006). Long-term change in the sensitivity of tree-ring growth to climate forcing in Larix decidua. New Phytologist, 170, 861-872.

Cheng, S. J., Bohrer, G., Steiner, A. L., Hollinger, D. Y., Suyker, A., Phillips, R. P., \& Nadelhoffer, K. J. (2015). Variations in the influence of diffuse light on gross primary productivity in temperate ecosystems. Agricultural and Forest Meteorology, 201, 98-110.

Ciais, P., Reichstein, M., Viovy, N., Granier, A., Ogée, J., Allard, V., ... Valentini, R. (2005). Europe-wide reduction in primary productivity caused by the heat and drought in 2003. Nature, 437, 529-533.

Cleland, E. E., Chuine, I., Menzel, A., Mooney, H. A., \& Schwartz, M. D. (2007). Shifting plant phenology in response to global change. Trends in Ecology and Evolution, 22, 357-365.

Cox, P. M., Pearson, D., Booth, B. B., Friedlingstein, P., Huntingford, C., Jones, C. D., \& Luke, C. M. (2013). Sensitivity of tropical carbon to climate change constrained by carbon dioxide variability. Nature, 494, 341-344.

Desai, A. R. (2010). Climatic and phenological controls on coherent regional interannual variability of carbon dioxide flux in a heterogeneous landscape. Journal of Geophysical Research: Biogeosciences, 115, G00J02. https://doi.org/10.1029/2010JG001423

Detto, M., Molini, A., Katul, G., Stoy, P., Palmroth, S., \& Baldocchi, D. (2012). Causality and persistence in ecological systems: A nonparametric spectral Granger causality approach. The American Naturalist, 179, 524-535.

Dietze, M. C., Vargas, R., Richardson, A. D., Stoy, P. C., Barr, A. G., Anderson, R. S., ... Chen, J. M. (2011). Characterizing the performance of ecosystem models across time scales: A spectral analysis of the North American Carbon Program site-level synthesis. Journal of Geophysical Research: Biogeosciences, 116, G04029. https://doi.org/ 10.1029/2011JG001661

Farquhar, G. D., \& Roderick, M. L. (2003). Pinatubo, diffuse light, and the carbon cycle. Science, 299, 1997-1998.

Fay, P. A., Carlisle, J. D., Knapp, A. K., Blair, J. M., \& Collins, S. L. (2003). Productivity responses to altered rainfall patterns in a C4-dominated grassland. Oecologia, 137, 245-251.

Fernández-Martínez, M., Vicca, S., Janssens, I., Sardans, J., Luyssaert, S., Campioli, M., ... Peñuelas, J. (2014). Nutrient availability as the key regulator of global forest carbon balance. Nature Climate Change, 4, 471-476.

Frank, D., Reichstein, M., Bahn, M., Thonicke, K., Frank, D., Mahecha, M. D., ... Zscheischler, J. (2015). Effects of climate extremes on the terrestrial carbon cycle: Concepts, processes and potential future impacts. Global Change Biology, 21, 2861-2880.

Fu, Z., Dong, J., Zhou, Y., Stoy, P. C., \& Niu, S. (2017). Long term trend and interannual variability of land carbon uptake-The attribution and processes. Environmental Research Letters, 12, 014018.

Fu, Z., Stoy, P. C., Luo, Y., Chen, J., Sun, J., Montagnani, L., ... Niu, S. (2017). Climate controls over the net carbon uptake period and amplitude of net ecosystem production in temperate and boreal ecosystems. Agricultural and Forest Meteorology, 243, 9-18.

Gatebe, C., Kuznetsov, A., \& Melnikova, I. (2014). Cloud optical parameters from airborne observation of diffuse solar radiation accomplished in USA and USSR in different geographical regions. International Journal of Remote Sensing, 35, 5812-5829.

Gatti, L., Gloor, M., Miller, J., Doughty, C., Malhi, Y., Domingues, L., ... Lloyd, J. (2014). Drought sensitivity of Amazonian carbon balance revealed by atmospheric measurements. Nature, 506, 76-80.

Griffis, T. J., \& Rouse, W. R. (2001). Modelling the interannual variability of net ecosystem $\mathrm{CO}_{2}$ exchange at a subarctic sedge fen. Global Change Biology, 7, 511-530.

Grinsted, A., Moore, J. C., \& Jevrejeva, S. (2004). Application of the cross wavelet transform and wavelet coherence to geophysical time series. Nonlinear Processes in Geophysics, 11, 561-566.

Gu, L., Baldocchi, D. D., Wofsy, S. C., Munger, J. W., Michalsky, J. J., Urbanski, S. P., \& Boden, T. A. (2003). Response of a deciduous 
forest to the Mount Pinatubo eruption: Enhanced photosynthesis. Science, 299, 2035-2038.

Guo, Q., Hu, Z., Li, S., Li, X., Sun, X., \& Yu, G. (2012). Spatial variations in aboveground net primary productivity along a climate gradient in Eurasian temperate grassland: Effects of mean annual precipitation and its seasonal distribution. Global Change Biology, 18, 3624-3631.

Guo, Q., Hu, Z., Li, S., Yu, G., Sun, X., Zhang, L., ... Zhao, W. (2015). Contrasting responses of gross primary productivity to precipitation events in a water-limited and a temperature-limited grassland ecosystem. Agricultural and Forest Meteorology, 214, 169-177.

Harper, C. W., Blair, J. M., Fay, P. A., Knapp, A. K., \& Carlisle, J. D. (2005). Increased rainfall variability and reduced rainfall amount decreases soil $\mathrm{CO}_{2}$ flux in a grassland ecosystem. Global Change Biology, 11, 322-334.

Heisler-White, J. L., Blair, J. M., Kelly, E. F., Harmoney, K., \& Knapp, A. K. (2009). Contingent productivity responses to more extreme rainfall regimes across a grassland biome. Global Change Biology, 15, 2894-2904.

Heisler-White, J. L., Knapp, A. K., \& Kelly, E. F. (2008). Increasing precipitation event size increases aboveground net primary productivity in a semi-arid grassland. Oecologia, 158, 129-140.

Houghton, R. A. (2000). Interannual variability in the global carbon cycle. Journal of Geophysical Research: Atmospheres, 105, 20121-20130.

Houghton, R. A. (2010). How well do we know the flux of $\mathrm{CO}_{2}$ from land-use change? Tellus B, 62, 337-351.

Hui, D., Luo, Y., \& Katul, G. (2003). Partitioning interannual variability in net ecosystem exchange between climatic variability and functional change. Tree Physiology, 23, 433-442.

Huxman, T. E., Snyder, K. A., Tissue, D., Leffler, A. J., Ogle, K., Pockman, W. T., ... Schwinning, S. (2004). Precipitation pulses and carbon fluxes in semiarid and arid ecosystems. Oecologia, 141, 254-268.

Ichii, K., Hashimoto, H., Nemani, R., \& White, M. (2005). Modeling the interannual variability and trends in gross and net primary productivity of tropical forests from 1982 to 1999. Global and Planetary Change, 48, 274-286.

Jarvis, P., Rey, A., Petsikos, C., Wingate, L., Rayment, M., Pereira, J., ... Valentini, R. (2007). Drying and wetting of Mediterranean soils stimulates decomposition and carbon dioxide emission: The "Birch effect". Tree Physiology, 27, 929-940.

Jung, M., Reichstein, M., Schwalm, C. R., Huntingford, C., Sitch, S., Ahlström, A., ... Zeng, N. (2017). Compensatory water effects link yearly global land $\mathrm{CO}_{2}$ sink changes to temperature. Nature, 541, 516-520.

Keeling, C. D., Adams, J. A., Ekdahl, C. A., \& Guenther, P. R. (1976). Atmospheric carbon dioxide variations at the South Pole. Tellus, 28 , 552-564.

Keeling, C. D., Bacastow, R. B., Bainbridge, A. E., Ekdahl, C. A., Guenther, P. R., Waterman, L. S., \& Chin, J. F. (1976). Atmospheric carbon dioxide variations at Mauna Loa observatory, Hawaii. Tellus, 28, 538-551.

Keeling, C. D., Whorf, T., Wong, C., \& Bellagay, R. (1985). The concentration of atmospheric carbon dioxide at Ocean Weather Station P from 1969 to 1981. Journal of Geophysical Research, 90, 10511.

Keenan, T. F., Baker, I., Barr, A., Ciais, P., Davis, K., Dietze, M., ... Richardson, A. D. (2012). Terrestrial biosphere model performance for inter-annual variability of land-atmosphere $\mathrm{CO}_{2}$ exchange. Global Change Biology, 18, 1971-1987.

Keenan, T. F., Davidson, E., Moffat, A. M., Munger, W., \& Richardson, A. D. (2012). Using model-data fusion to interpret past trends, and quantify uncertainties in future projections, of terrestrial ecosystem carbon cycling. Global Change Biology, 18, 2555-2569.
Keenan, T. F., Gray, J., Friedl, M. A., Toomey, M., Bohrer, G., Hollinger, D. Y., ... Richardson, A. D. (2014). Net carbon uptake has increased through warming-induced changes in temperate forest phenology. Nature Climate Change, 4, 598-604.

Keenan, T. F., Prentice, I. C., Canadell, J. G., Williams, C. A., Wang, H., Raupach, M., \& Collatz, G. J. (2016). Recent pause in the growth rate of atmospheric $\mathrm{CO}_{2}$ due to enhanced terrestrial carbon uptake. Nature Communications, 7, 13428.

Keppel-Aleks, G., Wolf, A. S., Mu, M., Doney, S. C., Morton, D. C., Kasibhatla, P. S., ... Randerson, J. T. (2014). Separating the influence of temperature, drought, and fire on interannual variability in atmospheric $\mathrm{CO}_{2}$. Global Biogeochemical Cycles, 28, 1295-1310.

Kleeman, R., \& Moore, A. M. (1997). A theory for the limitation of ENSO predictability due to stochastic atmospheric transients. Journal of the Atmospheric Sciences, 54, 753-767.

Kljun, N., Black, T. A., Griffis, T. J., Barr, A. G., Gaumont-Guay, D., Morgenstern, K., ... Nesic, Z. (2006). Response of net ecosystem productivity of three boreal forest stands to drought. Ecosystems, 9, 1128-1144.

Knapp, A. K., Beier, C., Briske, D. D., Classen, A. T., Luo, Y., Reichstein, M., ... Weng, E. (2008). Consequences of more extreme precipitation regimes for terrestrial ecosystems. Bioscience, 58, 811-821.

Knapp, A. K., \& Smith, M. D. (2001). Variation among biomes in temporal dynamics of aboveground primary production. Science, 291, 481-484.

Knohl, A., \& Baldocchi, D. D. (2008). Effects of diffuse radiation on canopy gas exchange processes in a forest ecosystem. Journal of Geophysical Research: Biogeosciences, 113, G02023. https://doi.org/ 10.1029/2007JG000663

Knorr, W., Gobron, N., Scholze, M., Kaminski, T., Schnur, R., \& Pinty, B. (2007). Impact of terrestrial biosphere carbon exchanges on the anomalous $\mathrm{CO}_{2}$ increase in 2002-2003. Geophysical Research Letters, 34, L09703. https://doi.org/10.1029/2006GL029019

Krishnan, P., Black, T. A., Barr, A. G., Grant, N. J., Gaumont-Guay, D., \& Nesic, Z. (2008). Factors controlling the interannual variability in the carbon balance of a southern boreal black spruce forest. Journal of Geophysical Research: Atmospheres, 113, D09109. https://doi.org/ 10.1029/2007JD008965

Le Quéré, C., Andres, R. J., Boden, T. A., Conway, T., Houghton, R. A., House, J. I., ... Zeng, N. (2013). The global carbon budget 19592011. Earth System Science Data, 5, 165-185. https://doi.org/ 10.5194/essd-5-165-2013

Le Quéré, C., Orr, J. C., Monfray, P., Aumont, O., \& Madec, G. (2000). Interannual variability of the oceanic sink of $\mathrm{CO}_{2}$ from 1979 through 1997. Global Biogeochemical Cycles, 14, 1247-1265.

Le Quéré, C., Peters, G. P., Andres, R. J., Andrew, R., Boden, T., Ciais, P., ... Zaehle, S. (2014). Global carbon budget 2013. Earth System Science Data, 6, 235-263.

Luo, Y. (2007). Terrestrial carbon-cycle feedback to climate warming. Annual Review of Ecology, Evolution, and Systematics, 683-712.

Luo, Y., Keenan, T. F., \& Smith, M. (2015). Predictability of the terrestrial carbon cycle. Global Change Biology, 21, 1737-1751.

Luo, Y., Randerson, J. T., Abramowitz, G., Bacour, C., Blyth, E., Carvalhais, N., ... Zhou, X. H. (2012). A framework for benchmarking land models. Biogeosciences, 9, 3857-3874.

Ma, Z., Peng, C., Zhu, Q., Chen, H., Yu, G., Li, W., ... Zhang, W. (2012). Regional drought-induced reduction in the biomass carbon sink of Canada's boreal forests. Proceedings of the National Academy of Sciences USA, 109, 2423-2427.

Mahecha, M. D., Reichstein, M., Jung, M., Seneviratne, S. I., Zaehle, S., Beer, C., ... Moors, E. (2010). Comparing observations and process- 
based simulations of biosphere-atmosphere exchanges on multiple timescales. Journal of Geophysical Research: Biogeosciences, 115, G02003. https://doi.org/10.1029/2009JG001016

Mercado, L. M., Bellouin, N., Sitch, S., Boucher, O., Huntingford, C., Wild, M., \& Cox, P. M. (2009). Impact of changes in diffuse radiation on the global land carbon sink. Nature, 458, 1014-1017.

Navrátil, M., Špunda, V., Marková, I., \& Janouš, D. (2007). Spectral composition of photosynthetically active radiation penetrating into a Norway spruce canopy: The opposite dynamics of the blue/red spectral ratio during clear and overcast days. Trees, 21, 311-320.

Nemani, R. R., Keeling, C. D., Hashimoto, H., Jolly, W. M., Piper, S. C., Tucker, C. J., ... Running, S. W. (2003). Climate-driven increases in global terrestrial net primary production from 1982 to 1999. Science, 300, 1560-1563.

Nijp, J. J., Limpens, J., Metselaar, K., Peichl, M., Nilsson, M. B., Zee, S. E., \& Berendse, F. (2015). Rain events decrease boreal peatland net $\mathrm{CO}_{2}$ uptake through reduced light availability. Global Change Biology, 21, 2309-2320.

Novick, K. A., Ficklin, D. L., Stoy, P. C., Williams, C. A., Bohrer, G., Oishi, A. C., ... Philips, R. P. (2016). The increasing importance of atmospheric demand for ecosystem water and carbon fluxes. Nature Climate Change, 6, 1023-1027.

Novick, K. A., Stoy, P. C., Katul, G. G., Ellsworth, D. S., Siqueira, M. B. S., Juang, J., \& Oren, R., (2004). Carbon dioxide and water vapor exchange in a warm temperate grassland. Oecologia, 138, 259-274.

Novick, K. A., Oishi, A. C., Ward, E. J., Siqueira, M., Juang, J. Y., \& Stoy, P. C. (2015). On the difference in the net ecosystem exchange of $\mathrm{CO}_{2}$ between deciduous and evergreen forests in the southeastern United States. Global Change Biology, 21, 827-842.

Oliphant, A., Dragoni, D., Deng, B., Grimmond, C., Schmid, H.-P., \& Scott, S. (2011). The role of sky conditions on gross primary production in a mixed deciduous forest. Agricultural and Forest Meteorology, 151, 781-791.

Pereira, J., Mateus, J., Aires, L., Pita, G., Pio, C., David, J., ... Rodrigues, A. (2007). Net ecosystem carbon exchange in three contrasting Mediterranean ecosystems - The effect of drought. Biogeosciences, 4, 791-802.

Piao, S., Ciais, P., Friedlingstein, P., Peylin, P., Reichstein, M., Luyssaert, S., ... Vesala, T. (2008). Net carbon dioxide losses of northern ecosystems in response to autumn warming. Nature, 451, 49-52.

Pinter, K., Balogh, J., \& Nagy, Z. (2010). Ecosystem scale carbon dioxide balance of two grasslands in Hungary under different weather conditions. Acta Biologica Hungarica, 61, 130-135.

Poulter, B., Frank, D., Ciais, P., Myneni, R. B., Andela, N., Bi, J., ... van der Werf, G. R. (2014). Contribution of semi-arid ecosystems to interannual variability of the global carbon cycle. Nature, 509, 600603.

Reichenau, T. G., \& Esser, G. (2003). Is interannual fluctuation of atmospheric $\mathrm{CO}_{2}$ dominated by combined effects of ENSO and volcanic aerosols? Global Biogeochemical Cycles, 17, 1094. https://doi.org/ 10.1029/2002GB002025, 4

Reynolds, J. F., Kemp, P. R., Ogle, K., \& Fernández, R. J. (2004). Modifying the 'pulse-reserve' paradigm for deserts of North America: Precipitation pulses, soil water, and plant responses. Oecologia, 141, 194-210.

Richardson, A. D., Hollinger, D. Y., Aber, J. D., Ollinger, S. V., \& Braswell, B. H. (2007). Environmental variation is directly responsible for shortbut not long-term variation in forest-atmosphere carbon exchange. Global Change Biology, 13, 788-803.

Richardson, A. D., Keenan, T. F., Migliavacca, M., Ryu, Y., Sonnentag, O., \& Toomey, M. (2013). Climate change, phenology, and phenological control of vegetation feedbacks to the climate system. Agricultural and Forest Meteorology, 169, 156-173.

Rocha, A. V., \& Goulden, M. L. (2008). Large interannual $\mathrm{CO}_{2}$ and energy exchange variability in a freshwater marsh under consistent environmental conditions. Journal of Geophysical Research: Biogeosciences, 113, G04019. https://doi.org/10.1029/2008JG000712

Roderick, M. L., Farquhar, G. D., Berry, S. L., \& Noble, I. R. (2001). On the direct effect of clouds and atmospheric particles on the productivity and structure of vegetation. Oecologia, 129, 21-30.

Sala, O., \& Lauenroth, W. (1982). Small rainfall events: An ecological role in semiarid regions. Oecologia, 53, 301-304.

Saleska, S. R., Miller, S. D., Matross, D. M., Goulden, M. L., Wofsy, S. C., Da Rocha, H. R., ... Silva, H. (2003). Carbon in Amazon forests: Unexpected seasonal fluxes and disturbance-induced losses. Science, 302, 1554-1557.

Schwalm, C. R., Williams, C. A., Schaefer, K., Arneth, A., Bonal, D., Buchmann, N., ... Richardson, A. D. (2010). Assimilation exceeds respiration sensitivity to drought: A FLUXNET synthesis. Global Change Biology, 16, 657-670.

Shao, J., Zhou, X., Luo, Y., Li, B., Aurela, M., Billesbach, D., ... Zhang, J. (2015). Biotic and climatic controls on interannual variability in carbon fluxes across terrestrial ecosystems. Agricultural and Forest Meteorology, 205, 11-22.

Shi, Z., Thomey, M., Mowll, W., Litvak, M., Brunsell, N. A., Collins, S., ... Luo, Y. (2014). Differential effects of extreme drought on production and respiration: Synthesis and modeling analysis. Biogeosciences, 11, 621-633.

Stoy, P. C., Dietze, M. C., Richardson, A. D., Vargas, R., Barr, A. G., Anderson, R. S., ... Weng, E. (2013). Evaluating the agreement between measurements and models of net ecosystem exchange at different times and timescales using wavelet coherence: An example using data from the North American Carbon Program Site-Level Interim Synthesis. Biogeosciences, 10, 6893-6909.

Stoy, P. C., Katul, G. G., Siqueira, M. B., Juang, J.-Y., McCarthy, H. R., Kim, H.-S., ... Oren, R. (2005). Variability in net ecosystem exchange from hourly to inter-annual time scales at adjacent pine and hardwood forests: A wavelet analysis. Tree Physiology, 25, 887-902.

Stoy, P. C., Katul, G. G., Siqueira, M. B., Juang, J.-Y., Novick, K. A., McCarthy, H. R., ... Oren, R. (2008). Role of vegetation in determining carbon sequestration along ecological succession in the southeastern United States. Global Change Biology, 14, 1409-1427.

Stoy, P. C., Richardson, A., Baldocchi, D., Katul, G., Stanovick, J., Mahecha, M., ... Williams, M. (2009). Biosphere-atmosphere exchange of $\mathrm{CO}_{2}$ in relation to climate: A cross-biome analysis across multiple time scales. Biogeosciences, 6, 2297-2312.

Thomey, M. L., Collins, S. L., Vargas, R., Johnson, J. E., Brown, R. F., Natvig, D. O., \& Friggens, M. T. (2011). Effect of precipitation variability on net primary production and soil respiration in a Chihuahuan Desert grassland. Global Change Biology, 17, 1505-1515.

Ueyama, M., Iwata, H., \& Harazono, Y. (2014). Autumn warming reduces the $\mathrm{CO}_{2}$ sink of a black spruce forest in interior Alaska based on a nine-year eddy covariance measurement. Global Change Biology, 20 (4), 1161-1173. 20, 1161-1173.

Unger, S., Máguas, C., Pereira, J. S., David, T. S., \& Werner, C. (2010). The influence of precipitation pulses on soil respiration - Assessing the "Birch effect" by stable carbon isotopes. Soil Biology and Biochemistry, 42, 1800-1810.

Valentini, R., Matteucci, G., Dolman, A., Schulze, E.-D., Rebmann, C., Moors, E., ... Jarvis, P. G. (2000). Respiration as the main determinant of carbon balance in European forests. Nature, 404, 861-865. 
Van der Werf, G. R., Randerson, J. T., Giglio, L., Collatz, G., Mu, M., Kasibhatla, P. S., ... van Leeuwen, T. T. (2010). Global fire emissions and the contribution of deforestation, savanna, forest, agricultural, and peat fires (1997-2009). Atmospheric Chemistry and Physics, 10, 11707-11735.

Van Gorsel, E., Berni, J., Briggs, P., Cabello-Leblic, A., Chasmer, L., Cleugh, H. A., ... Zegelin, S. (2013). Primary and secondary effects of climate variability on net ecosystem carbon exchange in an evergreen Eucalyptus forest. Agricultural and Forest Meteorology, 182, 248-256.

Wang, W., Ciais, P., Nemani, R. R., Canadell, J. G., Piao, S., Sitch, S., ... Myneni, R. B. (2013). Variations in atmospheric $\mathrm{CO}_{2}$ growth rates coupled with tropical temperature. Proceedings of the National Academy of Sciences USA, 110, 13061-13066.

Wang, X., Piao, S., Ciais, P., Friedlingstein, P., Myneni, R. B., Cox, P., ... Chen, A. (2014). A two-fold increase of carbon cycle sensitivity to tropical temperature variations. Nature, 506, 212-215.

Polley, H. W., Frank, A. B., Sanabria, J., \& Phillips, R. L. (2008). Interannual variability in carbon dioxide fluxes and flux-climate relationships on grazed and ungrazed northern mixed-grass prairie. Global Change Biology, 14, 1620-1632.

Welp, L., Randerson, J., \& Liu, H. (2007). The sensitivity of carbon fluxes to spring warming and summer drought depends on plant functional type in boreal forest ecosystems. Agricultural and Forest Meteorology, 147, 172-185.

Wen, X.-F., Wang, H.-M., Wang, J.-L., Yu, G.-R., \& Sun, X.-M. (2010). Ecosystem carbon exchanges of a subtropical evergreen coniferous plantation subjected to seasonal drought, 2003-2007. Biogeosciences, 7, 357-369.

Williams, M., Richardson, A. D., Reichstein, M., Stoy, P. C., Peylin, P., Verbeeck, H., ... Wang, Y.-P. (2009). Improving land surface models with FLUXNET data. Biogeosciences, 6, 1341-1359.

Wolf, S., Keenan, T. F., Fisher, J. B., Baldocchi, D. D., Desai, A. R., Richardson, A. D., ... van der Laan-Luijkx, I. T. (2016). Warm spring reduced carbon cycle impact of the 2012 US summer drought. Proceedings of the National Academy of Sciences USA, 113, 5880-5885.

Wu, C., Gonsamo, A., Chen, J. M., Kurz, W. A., Price, D. T., Lafleur, P. M., .. Munger, J. W. (2012). Interannual and spatial impacts of phenological transitions, growing season length, and spring and autumn temperatures on carbon sequestration: A North America flux data synthesis. Global and Planetary Change, 92, 179-190.

Xia, J., Niu, S., Ciais, P., Janssens, I. A., Chen, J., Ammann, C., ... Luo, Y. (2015). Joint control of terrestrial gross primary productivity by plant phenology and physiology. Proceedings of the National Academy of Sciences USA, 112, 2788-2793.

Xiao, J., Liu, S., \& Stoy, P. C. (2016). Preface: Impacts of extreme climate events and disturbances on carbon dynamics. Biogeosciences, 13, 3665-3675.

Xiao, J., Ollinger, S. V., Frolking, S., Hurtt, G. C., Hollinger, D. Y., Davis, K. J., ... Suyker, A. E. (2014). Data-driven diagnostics of terrestrial carbon dynamics over North America. Agricultural and Forest Meteorology, 197, 142-157.

Yuan, W., Luo, Y., Richardson, A. D., Oren, R., Luyssaert, S., Janssens, I. A., .. Wofsy, S. C. (2009). Latitudinal patterns of magnitude and interannual variability in net ecosystem exchange regulated by biological and environmental variables. Global Change Biology, 15, 2905-2920.

Yvon-Durocher, G., Jones, J. I., Trimmer, M., Woodward, G., \& Montoya, J. M. (2010). Warming alters the metabolic balance of ecosystems. Philosophical Transactions of the Royal Society B: Biological Sciences, 365(1549), 2117-2126.

Zeng, N., Mariotti, A., \& Wetzel, P. (2005). Terrestrial mechanisms of interannual $\mathrm{CO}_{2}$ variability. Global Biogeochemical Cycles, 19, GB1016. https://doi.org/10.1029/2004GB002273
Zhang, J., Wu, L., Huang, G., \& Notaro, M. (2011). Relationships between large-scale circulation patterns and carbon dioxide exchange by a deciduous forest. Journal of Geophysical Research: Atmospheres, 116. D04102, doi:10.1029/2010JD014738.

Zhang, L., Guo, H., Jia, G., Wylie, B., Gilmanov, T., Howard, D., ... Kato, T. (2014). Net ecosystem productivity of temperate grasslands in northern China: An upscaling study. Agricultural and Forest Meteorology, 184, 71-81.

Zhang, M., Yu, G.-R., Zhang, L.-M., Sun, X.-M., Wen, X.-F., Han, S.-J., \& Yan, J.-H. (2010). Impact of cloudiness on net ecosystem exchange of carbon dioxide in different types of forest ecosystems in China. Biogeosciences, 7, 711-722.

Zhang, M., Yu, G.-R., Zhuang, J., Gentry, R., Fu, Y.-L., Sun, X.-M., ... Li, Y.-N. (2011). Effects of cloudiness change on net ecosystem exchange, light use efficiency, and water use efficiency in typical ecosystems of China. Agricultural and Forest Meteorology, 151, 803-816.

Zhang, X., Gurney, K. R., Peylin, P., Chevallier, F., Law, R. M., Patra, P. K., ... Krol, M. (2013). On the variation of regional $\mathrm{CO}_{2}$ exchange over temperate and boreal North America. Global Biogeochemical Cycles, 27, 991-1000.

Zhang, Y., Xiao, X., Zhou, S., Ciais, P., McCarthy, H., \& Luo, Y. (2016). Canopy and physiological controls of GPP during drought and heat wave. Geophysical Research Letters, 43, 3325-3333.

Zhou, S., Zhang, Y., Ciais, P., Xiao, X., Luo, Y., Caylor, K. K., ... Wang, G. (2017). Dominant role of plant physiology in trend and variability of gross primary productivity in North America. Scientific Reports, 7 , 41366.

Zscheischler, J., Mahecha, M. D., von Buttlar, J., Harmeling, S., Jung, M., Rammig, A., ... Reichstein, M. (2014). A few extreme events dominate global interannual variability in gross primary production. Environmental Research Letters, 9, 035001.

\section{BIOSKETCH}

SHuL Niv obtained her PhD at the University of Chinese Academy of Sciences in 2004, and completed postdoctoral studies at the University of Oklahoma. Currently, she is a Professor in the Institute of Geographic Sciences and Natural Resources Research, Chinese Academy of Sciences. Her research focuses on the dynamics of ecosystem carbon and nitrogen cycling and their responses and feedbacks to global change. She has published $>70$ papers in peer-reviewed journals, including Nature, Proceedings of the National Academy of Science USA, Ecology Letters and Global Change Biology. Her $\mathrm{H}$ index is currently 28.

\section{SUPPORTING INFORMATION}

Additional Supporting Information may be found online in the supporting information tab for this article.

How to cite this article: Niu S, Fu Z, Luo Y, et al. Interannual variability of ecosystem carbon exchange: From observation to prediction. Global Ecol Biogeogr. 2017;26:1225-1237. https:// doi.org/10.1111/geb.12633 